\title{
EDITORIAL
}

\section{The year that was......and years that will be!}

First birthday of a child is celebrated by great fervour by the parents; the reasons are not too far to seek. The uneventful first year of life is crucial to survival for every new born. Using the same analogy, the Indian Society of Neuroanaesthesiology and Critical Care (ISNACC) should be ecstatic of the fact that the Journal of Neuroanaesthesiology and Critical Care (JNACC) has stepped majestically into the second year of its life (publication). Everyone, even remotely connected to the Society, should be proud of its march into the second year. The collective efforts of all the Society members have proved the sceptics wrong. When it was decided to launch our very own journal, there were few murmurs of dissent and fewer vocal opponents to this proposal. However, egged on by the belief in the potentials of members, an irrevocable decision was taken to publish the journal and the result is there for everyone to see and appreciate. Here, I must warn you all with a word of caution, be wary of complacency creeping into us; the journal is still in its nascent stage and is facing some teething problems. I am certain every new journal must have gone through this stage and therefore, it should not be a cause of any big despondency. The next target before us is to get the journal indexed with various agencies. It should not be a brainer to underscore the publication of high quality of the articles to achieve this aim as well as for competing with other anaesthesia/neuroanaesthesia journals in the academic arena. It gives me a sense of relief that gradually the quality of manuscripts submitted to the journal is on the upswing. The editorial team is receiving fathomless support from our various distinguished reviewers. The reviewers should never take this job as a thankless one, rather they should know that the editorial team thinks high of them and has immense faith in their analytical abilities. It is an honour bestowed on them by everyone, including authors and the editorial board. They deserve all kudos for timely submission of their comments which

\begin{tabular}{|l|l|}
\hline \multicolumn{2}{|c|}{ Access this article online } \\
\hline Quick Response Code: & Website: \\
\hline & www.jnaccjournal.org \\
\cline { 2 - 2 } & \\
\hline
\end{tabular}

ultimately results in timely publication of each issue with respectable number of good articles.

To survive and go up the ladder in the academic world, there is pressure on all concerned, to enlist certain number of publications in their curriculum vitae. To meet this requirement and to increase the bulk of curriculum vitae, plagiarism is raising its ugly head. Many cases of this vile practice have been reported even by some reputable scientific journals. This practice not only tarnishes the reputation of the journal but more than that shows country's academia in poor light. Of course, the author/s will suffer in unmeasurable dimensions. Above all, such practice does not give any sense of satisfaction and pride to the authors. This will harm the credibility of the journal and delay/ mar the chances of indexing it with various agencies. Let us not fall prey to this false glory. Therefore, my humble plea to all, please shun this abhorrent, vile practice and achieve laurels by dint of innovation and hard work. Remember that there is no short cut to success. Publication of your original work will give you immense satisfaction and in return the journal too will reap the sweet fruits of it.

One heartening outcome of publication of JNACC is that it has awakened the research instinct of many anaesthesiologists, young as well as old, a fact born out from the increasing number of manuscripts received by the editorial office. While on the one hand, this will raise the standards of research in the field of neuroanaesthesia in India, on the other hand, it will offer golden opportunity to many budding neuroanaesthesiologist/anaesthesiologists of showcasing their research abilities. This bodes well not only for neuroanaesthesia but anaesthesia fraternity at large. However, the editorial board has noticed that many articles are either designed poorly or written improperly. Methodology constitutes the heart of a scientific study; therefore, try to remove any flaw/confounds in the designing of a study by discussing with your peers. At the designing stage, a statistician plays an important role. Therefore, his/her involvement will strengthen the study design. My sincere advice to the younger generation and to those contemplating writing a scientific paper for the first time, please seek guidance from your seniors while putting your thoughts in black and white. Do not be hesitant to learn something new from any source, may be he/ she is your junior colleague with expertise in writing 
scientific papers. This will help improve your writing skills and, thereby, increase the rate of acceptance of your work, which otherwise is abysmal in most journals.

\section{Parmod K Bithal}

Department of Neuroanaesthesiology, All India Institute of Medical Sciences, New Delhi, India
Address for correspondence: Prof. Parmod K Bithal,

Department of Neuroanaesthesiology, All India Institute of Medical Sciences, New Delhi - 110 029, India. E-mail: bithal.parmod@gmail.com

How to cite this article: Bithal PK. The year that was......and years that will be!. J Neuroanaesthesiol Crit Care 2015;2:1-2.

Source of Support: Nil, Conflict of Interest: None declared.

\section{"Quick Response Code" link for full text articles}

The journal issue has a unique new feature for reaching to the journal's website without typing a single letter. Each article on its first page has a "Quick Response Code". Using any mobile or other hand-held device with camera and GPRS/other internet source, one can reach to the full text of that particular article on the journal's website. Start a QR-code reading software (see list of free applications from http://tinyurl.com/ yzlh2tc) and point the camera to the QR-code printed in the journal. It will automatically take you to the HTML full text of that article. One can also use a desktop or laptop with web camera for similar functionality. See http://tinyurl.com/2bw7fn3 or http://tinyurl.com/3ysr3me for the free applications. 